\title{
長周期波の設計への反映に関する \\ 取り組みの現状と課題 \\ VISION AND PROBREMS FOR REFLECTION OF EFFECTS OF LONG-PERIOD \\ WAVES INTO DESIGN OF COASTAL FACILITIES
}

\author{
関本恒浩 \\ Tsunehiro SEKIMOTO \\ 正会員 博(工) 五洋建設株式会社＼cjkstart技術研究所（テ329-2746 栃木県那須郡西那須野町四区町1534-1）
}

\begin{abstract}
The long-period waves have been researched in recent years because of its importance in the various problems of coastal engineering, such as long-period oscillation, long-period motions of moored vessels, sediment transport, wave-overtopping and stability of coastal structures. Importance of long period waves have been well recognized, however, its reflection of effects of the long-period waves into design of coastal facilities is not sufficient.

In this paper, we review previous researches on the long period waves and consider the problems in the reflection of effects of long-period waves into design of coastal facilities.
\end{abstract}

Key Words : long-period waves, design, coastal facilities, wave-overtopping, sediment transport, long-period oscillation, slow drift motion of moored vessels

\section{1.はじめに}

長周期波は，数十秒から数時間を有する周期帯の 波動の一般名称であるが, ここでは周期数分程度の 長周期波を対象としている。長周期波は1950年前後 にはじめて観測され ${ }^{1), 2)}$, 海岸工学上の未解決課題 と位置づけられたのは意外と古い。しかしながら， その後 20 年ほどの間は，波群による長周期拘束波の 存在が示された程度で, 長周期波に関する研究はあ まり進展を見なかった。1970年代後半になって現地 観測による現象の理解が試みられたものの理論的な 解明が十分に進展しなかったため，十分な成果が得 られなかった．1980年代に入って，砕波帯内での サーフビートの発生理論が提案され3)，長周期波発 生のメカニズムに関する研究の糸口が見いだされた ことや，WKB法を用いて長周期波を解析的あるい は数值的に検討する手法が発展されたこと出などに よって理論的な下地ができた。1990年代になると海 岸や港湾に関わる諸現象が長周期波と深く関わって きていることが現地観測などによって明らかにされ， 工学的重要性が認識されるようになった。最近は, 非常に精度の良い水理実験が行われるようになると ともに，電算機の進歩によりBoussinesq方程式等の 数值解析手法が実用化されたことにより, 現象面と 理論面の整合性がある程度詳細に議論できるに至り， 応用的な研究も精力的に取り組まれるようになった。
この周期帯の長周期波の問題は，港内副振動，係 留船舶の動摇, 海浜変形, 護岸や防波堤の安定性な ど海岸工学上のさまざまな問題と関連することが知 られている。しかしながら, 長周期波の重要性は認 めつつも, 設計などへの反映が, 現在十分に進んで いないとの印象が強い. 本研究では, 既往の文献や 被災事例に基づき，長周期波の設計への反映状況を 概観するとともに，その取り組みのための課題につ いて考察した。

\section{2. 長周期波による被災事例}

まず，既往文献に見られる周期 1 数分程度の長 周期波が関与したと考えられる被災事例を抽出した。 長周期波が関係したと報告されている災害事例が非 常に少ない。この理由は, (1)長周期波の発生や伝播 などの現象の理解が十分でなかったため, 長周期波 の重要性の認識が薄かったこと, (2)長周期波が顕著 になるような条件では, 波浪も非常に大きく, 高潮 も同時に起こる可能性が高いため, 高波や高潮が直 接的な被災原因としてクローズアップされ，長周期 波の影響が見過ごされてしまうこと, (3)これまでの 波浪観測では高波浪時に波浪デー夕の欠測が多く， 被災時の波浪条件の検討が詳細かつ十分に行えない ことなどが考えられる。

表-1は，既往の文献より抽出した被災事例の一覧 
表-1 長周期波が影響したと考えられる被災事例

\begin{tabular}{|c|c|c|c|}
\hline & 地点 & 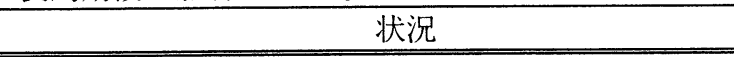 & 出典 \\
\hline \multirow[t]{5}{*}{ 越波 } & 富士海岸 & TP+13mの護岸を越波, 死者10数名 & 佐藤ら ${ }^{5)}$ \\
\hline & 楚州海岸 & DL+7.5mの護岸を越波，10kNの根固打上げ & 仲座 $5^{6)}$ \\
\hline & 駿河海岸 & 背後地の浸水 & 佐藤ら ${ }^{7)}$ \\
\hline & 西湘海岸 & 約 $1 \mathrm{~km}$ にわたり $100 \mathrm{~m}^{3}$ 超える砂の打ち上げ & 佐藤ら ${ }^{8)}$ \\
\hline & 下田港海岸 & 背後地の浸水（越流水深 $0.5 \sim 1.0 \mathrm{~m})$ & 平石ら ${ }^{9)}$ \\
\hline \multirow[t]{3}{*}{ 防波堤の安定 } & 前泊港 & 全区間 $(300 \mathrm{~m})$ のケーソンが滑動, 消波工飛散 & 仲座 $5^{6)}$ \\
\hline & 仲田港 & $230 \mathrm{~m}$ 間の消波ブロック $(20 \mathrm{kN})$ 飛散 & 仲座ら ${ }^{6)}$ \\
\hline & 苓北港 & 200m区間のケーソンが滑動 & 田中ら ${ }^{10)}$ \\
\hline \multirow[t]{2}{*}{ 水位上昇 } & 港川漁港 & 港内係留船舶の流出・破壊 & 仲座ら ${ }^{6)}$ \\
\hline & 八重根漁港 & 港内冠水による冷蔵施設の浸水 & 清水ら ${ }^{11)}$ \\
\hline \multirow[t]{3}{*}{ 船体動摇 } & 能代港 & 92～94年にかけて係留索切断 3 回 & 平石 ${ }^{12)}$ \\
\hline & 苫小牧東港 & 85～94年にかけて係留索切断25回 & 平石ら ${ }^{13)}$ \\
\hline & 志布志港 & 90～94年にかけて係留索切断20回，防舷材破損 2 回 & 平石 $5^{12), 13)}$ \\
\hline
\end{tabular}

を示したものである．以下にこれらの被災事例につ いて長周期波の影響とした判断根拠を簡単に解説す る.

\section{（1）越波被害}

越波災害では従来の設計法の範囲内では，越波流 量を説明できず，それ以外の現象を考慮しなければ ならないことが指摘されている。富士海岸の被災時 は，沼津港の潮位計で長周期波が観測されたことよ り，長周期波の影響が指摘されている。また，その 他の地点では目撃者の証言により, 数分の周期で越 波が繰り返していたということや被災時の打上げ高 や越波流量の追算結果から，長周期波の影響である ことが推論されている。

\section{（2）防波堤の安定}

防波堤の被災についても，越波の場合と同様に， 従来の設計法では防波堤が不安定になる要因が見当 たらず，設計で考慮されていない外力が作用したと 結論されている。このうち苓北港の防波堤の被災に 対しては，防波堤前後の長周期波を静水圧的に与え ることによって，被災時の滑動安全率が 1 を下回る ことを示し，長周期波の影響があったとする根拠と

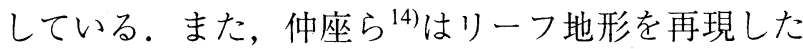
水理模型実験を実施し，リーフ上では長周期波が段 波状に伝播し，防波堤などの構造物に大きな波力が 作用することを確認している.

\section{（3）港内水位上昇}

ここに示した港内の水位上昇による港内の冠水被 害は, 漁港という比較的小規模な範囲を対象として おり, 長周期波の水位変動が直接寄与している可能 性は高いが，港内副振動とも関係していると考えら れる。港川漁港の被災では，漁港内に残された水位 の痕跡が，観測波浪に基づく高山らによるリーフ状 の水位上昇量評価式では説明できないことから長周 期波の影響であると推測している。また，八重根漁 港の被害については, 水理模型実験および
Boussinesq方程式による数值解析によって, 平均水 位が岸壁を超える様子を再現し，長周期波の影響を 明らかにしている。

\section{（4）船体動摇}

ここに示した被災事例については, 長周期船体動 摇発生のメカニズムはほぼ解明されており, 外力で ある長周期波と係留系の固有周期が一致することに よって大きな船体動摇を生ずることが，現地観測や 数值解析などによって検証されている。また係留船 舶の動摇は, 長周期波の港内の特性とも関連してい るため, 当然港内副振動とも関連しており, 被災状 況の確認の再に, 港内副振動の検討が併せて行われ ているものもある.

なお，長周期波による荷役障害は，潜在的には もっと多いものと推測されるが, 被災事例として報 告されているのはほんの一部に過ぎないと考えられ る.

\section{3. 長周期波に関する研究の状況と設計への取 り組みの現状}

\section{（1）入射長周期波}

入射長周期波の波高や振幅を評価しようとする試 みは長周期波の発見当初からあり，Munk ${ }^{1)}$ Tucker ${ }^{2}$ によって，長周期波の波高は入射波高の1割 程度であることが示された。その後，合田 ${ }^{15}$ によっ て入射波の外力特性と関連づけた一般性のある経験 式が提案され，山口・畑田 ${ }^{16)}, \mathrm{Katoh}^{17)}$ などによって この式の妥当性が検討されている. Bowers ${ }^{18)}$ は, 解 析的扱いの容易な方向分布関数を用いた解析と現地 観測結果に基づく検討を行い，非線形拘束波および 自由長周期波の有義波高を推定する式を提案してい る。また，渥美ら ${ }^{19)}$ ，山村・青木 ${ }^{20)}$, 堀沢ら ${ }^{21)}$ は, 長周期波の有義波高は, 基本波の有義波高と有義波 周期の積にほぼ比例することを示している。これは， Bowers ${ }^{18)}$ が示した自由長周期波の推定式とほほ同じ 
傾向となる。しかしながら，比例定数は観測地点に よって異なり，一般性のあるものとはなっていない。

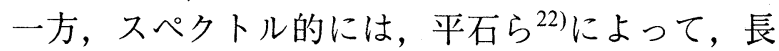
周期波の標準スペクトルが提案されている。これは， 長周期波のスペクトルを矩形で近似しょうとするも のである。しかしながら，この方法も長周期波の工 ネルギーレベルすなわち波高の決定には任意性があ り，一般性のあるものとはなっていない。

関本ら ${ }^{23)}$ や佐藤ら ${ }^{24)}$ をはじめ，観測される長周 期波は，ローカルな波浪と相関があることが示され ており，その海域で波浪と関連して発生しているこ とは明らかである。このことを踏まえ，中畑ら ${ }^{25), 26)}$ は，波浪および長周期波の方向分散性を考慮して水

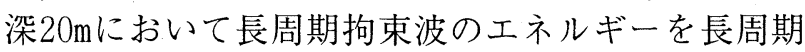
波の入力情報として与えることによって，海域の長 周期波を定量的に精度良く評価できることを示して いる。

以上のレビューより，入射波としての長周期波の 特性は明らかになりつつあるが，設計に用いられる ような一般的な評価法はいまだ確立された方法がな いというのが現在の状況である。

\section{（2）越波および打ち上げ高}

平石 ${ }^{9)}$ は，下田港海岸に扔ける越波災害を，長 周期波を考慮して緩傾斜上の打上げ高を評価するこ とによって説明している。また，越波流量に関する 検討も行い，長周期波の越波に及ぼす影響が非常に 大きいことを例証している。このときの長周期波の 評価は，合田による経験式 ${ }^{15)}$ が用いられている。

また，佐藤ら ${ }^{7)}{ }^{8)}$ 西湘海岸および駿河海岸にお ける越波災害を説明するため，長周期波を考慮した 打上げ高の計算を行い長周期波が越波に支配的であ ることを明らかにしている。ここでの長周期波の評 価は，現地観測結果およびこれを元に 2 次元の線形 長波理論解による推定値を用いている.

これらの研究では，被災時の状況を定性的に評価 しているに過ぎず，打上げ高さや越波流量に対する 検証は現状では十分に行われているとは言い難い.

したがって，現状では長周期波の影響を設計に反映 させるまでには至っていない.しかしながら, 数值 波動水路を用いた越波の検討 ${ }^{27)}$ では，波高と越波流 量を関連付けた従来の越波評価法でも，長周期波に よる平均水位を適切に評価すれば，越波流量を適切 に評価できることが示唆されており，越波や打ち上 げ高に対して平石らや佐藤らの評価手法の設計への 適用の可能性はあるものと考えられる。

越波や打ち上げ高に関する設計図表や設計公式に は, 不規則波実験に基づくものもあり，不規則波実 験の際に付随的に発生する長周期波が含まれる。こ のため, 結果として設計図表や設計公式の中にある 程度は暗黙のうちに長周期波が考慮されているもの と考えられるので，長周期波を考慮する際には注意 が必要である。

\section{（3）堤体の安定性}

長周期波が構造物の安定性などに影響することが, 喜岡 ${ }^{28)}$, 喜岡 ${ }^{29)}$, 仲座・日野6), 仲座 ${ }^{30)}$, 関本ら 31), 清水ら ${ }^{32)},{ }^{33)} に よ り$ 示唆されているものの, 系統 だった研究は現在のところほとんど実施されていな い.

\section{（4）港内副振動}

長周期波の港内副振動については，まずBowers ${ }^{34)}$ が港口の狭い港湾に波群とともに入射した長周期波 の挙動を理論的に調べている。また，喜岡ら ${ }^{35)}$, $\mathrm{Mei} \cdot \mathrm{Agnon}^{36)}$ は外洋に面した矩形港湾における長周 期波の応答特性を，またWu· $\mathrm{Liu}^{37}$ は港口が 2 本の防 波堤で遮蔽された矩形港湾を対象とした理論解析を, maltiple-scale法を用いて行っている.

一方で，波動方程式による数值的な評価も行われ ている。関本ら ${ }^{38}$ によれば，防波堤背後では波浪が 回折によって急激に減衰するため, 拘束波はほとん どそのまま自由波に置き換わることが理論的に示さ れており，港口での長周期波が適切に評価できれば, 線形長波方程式による解法も比較的精度良く港内の 長周期波を評価できる。また, 強制項にラディエー ションストレスを考慮した線形長波方程式を用いた

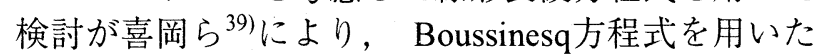
港内副振動の検討が, 金山ら ${ }^{40)}$, 喜岡・柏原 ${ }^{41)}$, 藤 畑ら ${ }^{42)}$ ，Cruzら ${ }^{43)}$ なとによって行われている。また， 喜岡・柏原 ${ }^{44)}$, 藤畑ら ${ }^{45)}$ によって入射波の多方向性 も考慮できるようになっており，精度の良い解析が 可能となっている。谢波条件や境界条件の設定法 についてはさらに検討が必要と考えられるものの, 実務ですでに設計などに用いられており，実用段階 であるといえる。

\section{（5）船体動摇}

船体動摇に関連する既往の研究を以下に概観する。 まず，仙台新港については，200,000DWT級船舶 の栈橋での係留可否記録結果および波浪観測記録を もとに, 波群統計量や長周期波と係留可否状況の関 係について検討が行われている ${ }^{43)}$.

苫小牧東港では，港内長周期波の特性と船体動摇 に関する現地観測の実施 ${ }^{44)}$, 荷役限界長周期波高の 評価と港外の長周期波高を推定するための経験式の 提案 $\left.{ }^{45)}, 46\right)$ 拉よび長周期波対策として, 係留索の変更 による長周期動摇の抑制や防波堤レイアウトの変更 による長周期波に対する稼働率の評価 ${ }^{19)}$ といった長 周期波に対する検討が継続的に実施されている.

田端らは能代港に打いて波浪の現地観測と線形長 波理論に基づく数值計算を実施し，港内副振動と船 体動摇の関係を明らかにしている47).

九州電力苓北火力発電所専用港湾においても現地 観測による長周期波の評価, 船体動摇を考慮した荷 役限界波高の算定, Boussinesq方程式による港内波 浪評価掞よび数值シミュレーションによる船体動摇 量の精度良い評価法の提案が行われている ${ }^{48,411,49)}$.

鹿島港についても, 同様な現地観測と検討が行わ 
れ，他地点と同様に港外から港内への長周期波の伝 播特性が調べられるとともに, 係留系の固有周期と 長周期波の周期が同調することによって船体動摇が 大きくなることが示されている50).

白石 ${ }^{51)}$ も, 係留船舶の長周期動摇に関する現地 観測をもとに，数值シミュレーションによる観測結 果の再現を行っている.

このように，船体動摇に関しては長周期波の港内 への伝播も含め, 数多くの研究が進められており, 港口での長周期波が与えられれば船体動摇量を定量 的に評価することが可能となっている。このように 長周期波に関する問題の中でも最も積極的に設計へ の取り組みが行われており，すでに実務設計レベル にあると考えられる。

\section{（6）海浜变形}

Bowen·Inmann ${ }^{52)}$ は，エッジ波によって三日月型 砂州が生じ，沿岸方向の波長がエッジ波の波長の 1/2 となることを理論的に導いている. Short ${ }^{53)}$ は北 アラスカにおいて，Katoh ${ }^{17}$ は石川県羽咋海岸にお いて長周期波によって沿岸の多段砂州が形成してい ることを示している。また, 松岡ら ${ }^{55)}$ は, 漁港内の 航路堆砂問題について長周期波の寄与があることを 指摘している. 長周期波による流速变動自体は非常 に小さいため, 上述のいずれについても長周期波が 漂砂の直接の外力とはならず，基本波の砕波などに よって浮遊状態となった砂が, 長周期波によって移 動・堆積するとされている。

一方, 長周期波が漂砂現象に直接影響するとされ ているものもある. 柴山ら ${ }^{55)}$ 佐藤 ·光信 ${ }^{56)}$ は局所 漂砂量に及ぼす長周期波の影響が大きく, 特に汀線 付近で大きいことを示している。高波浪時のバーム の侵食と長周期波の関係については, 加藤ら ${ }^{57)} に$ よって検討されており，バームの侵食には長周期波 が直接関係することを示すとともに，バーム侵食限 界と侵食域上部に位置する堆積限界について外力条 件と関連づけて評価している。

Dibajniaら ${ }^{58)}$ は，シートフロー漂砂におよぼす長 周期波の影響を調べており，シートフロー漂砂の場 合, 長周期波が存在すると漂砂量が一般的には大き くなるが，拘束波が卓越する場合には減少する傾向 があることを示している．ただし，基本波と長周期 波の位相状態によっては漂砂量が増える場合がある ことも同時に示している.

漂砂現象におよぼす長周期波の影響については,
未解明な部分がいまだ多く残されているといえる.

\section{4. 長周期波の設計への取り組みに対する課題}

これまでの考察を踏まえ, 長周期波の設計への取 り組みに対する課題を整理する。まず，ここまでの 研究現状と実務への反映状況を把握するため, 表-2 のような整理を行った。この表の列は左より, 各現 象毎にその主要因, 主要因に対する長周期波の寄与 の割合をオーダーで表したもの, 各現象を設計にお いて評価する際の主要因に対するオーダーを表した もの，および設計における評価量に対する長周期波 の寄与度のオーダー, すなわち相対的な長周期波の 寄与度を大まかに示したものである。なお，設計の 際の評俩オーダーは, 現状にお打る評価精度とみな すこともできる。これによると，構造物の安定性お よび海浜変形は, 設計精度に対する相対的な長周期 波の寄与度が小さい。 それ以外は, 両者はほぼ同じ オーダーとなる。この結果と被災事例を比べると， 構造物の被災についてはリーフ上の特殊なケースを 除くと, 既往文献では 1 事例しかなく, 越波や船体 動摇が複数事例あることを説明できる。また，後者 は既往の研究事例が多く, この多くの研究成果に支 えられて現状において実務レベルにあり，設計への 展開が可能な事項でもある。すなわち, 長周期波の 現象への寄与に対して, 解析精度が十分でなければ 設計への反映が難しいことを表している.

したがって，実用レベルにあるものは今後どんど ん設計に取り入れていくべきであるし，そうでない ものは解析精度を上げる努力をする必要があると考 えられる. 以下に本検討を踏まえた長周期波の設計 への取り組みにおける現状と課題について列挙する。 (1)入射条件としての長周期波をどのように評価する かについては, 十分に研究が進められているとは言 えない.すなわち，現状では観測に基づき経験的に 決められた，海域毎の予測式に頼っているのが現状 である。これは, 浅海域での長周期波の挙動が十分 に解明されていないことによる。

(2)越波や打ち上げ高に関しては実用段階に近いと言 える。しかしながら，不規則波実験をもとにした設 計図表や設計公式には長周期波の影響が含まれるた め, 長周期波と基本波の重合の際に, 両者の位相条 件によって大きく結果が異なる可能性があり, 設計 の精度が要求される場合には, その評価が今後の課

表-2 長周期波に関係する現象の長周期波の相対的寄与

\begin{tabular}{|l|l|c|c|c|}
\hline \multicolumn{1}{|c|}{ 現 象 } & \multicolumn{1}{|c|}{ 主要因 } & $\begin{array}{c}\text { 長周期波の } \\
\text { 寄与度 }\end{array}$ & $\begin{array}{c}\text { 設計における } \\
\text { 評価オーダー }\end{array}$ & $\begin{array}{c}\text { 長周期波の } \\
\text { 相対的寄与度 }\end{array}$ \\
\hline 入射長周期波 & 波浪・波群 & 2次 & $1 \sim 2$ 次 & $1 \sim 2$ 次 \\
\hline 越波・打ち上げ & 波浪 & 2次 & 2 次 & 1 次 \\
\hline 構造物の安定性 & 波浪 & 2次 & 1 次 & 2 次 \\
\hline 港内副振動 & 長周期波 & 1 次 & 1 次 & 1 次 \\
\hline 船体長周期動摇 & 長周期波 & 1 次 & 1 次 & 1 次 \\
\hline 海浜変形 & 波浪・海浜流 & 2次 & 1 次 & 2 次 \\
\hline
\end{tabular}


題と考える.

(3)港内副振動の増幅メカニズムについては，拘束長 周期波から自由波への転換課程などが明らかにされ， 港口での長周期波情報が与えられれば定量的に予測 可能なレベルまで到達している。したがって, 海域 に対応する長周期波の経験的な予測が可能なところ では，十分に設計への反映が可能である。

(4)係留船舶の長周期動摇については, 港内波浪場が 評価できれば，定量的に評価できるレベルとなって おり，(3)と同様に海域に対応する長周期波の予測が 可能なところでは，設計への反映は十分可能といえ る。

(5)海浜変形に及ぼす影響については，漂砂に及ぼす 長周期波の影響も含め, 現状としては定量的には評 価できていない。海浜変形については，現状では設 計を議論できる段階ではないと言える。

(6)構造物に及ぼす影響については，研究として十分 に進んでいるとは言えないのが現状である。ただ， 波浪に比べ波長が 1 オーダー長いため，長周期波が 正確に評価できれば，潮位と似た扱いができると考 えてもよい.

\section{5. 終わりに}

設計という観点からみた長周期波に関連する項目 として，(1)入射長周期波の評価，(2)越波，(3)構造物 の安定性, (4)港内副振動, (5)係留船舶の長周期動摇, (6)海浜変形等について, 既往の研究および被災事例 をレビューし，設計への取り組みの現状をまとめた。 また，この現状を踏まえ，長周期波の設計への反映 に関する課題についての考察を行った。ここで, 最 も気になるのが入射長周期波の評価である。現状で は入射長周期波評価法で確立されたものはない。し かしながら，入射長周期波はすべての現象の入力と なるものであり，この評価法を確立することが長周 期波の設計への展開に向けて急務と言える.

\section{参考文献}

1) Munk,W.H. : Surf beats, Trns. A. G. U., Vol.30, No.6, pp.849-854, 1949.

2) Tucker,M.J. : Surf beats : sea wave of 1 to 5 min. period, Proc. Roy. Soc. London, Ser.A, Vol.202, pp.565-573, 1950.

3) Symonds, G., D. A. Huntley and A. J. Bowen : Twodimensional surfbeat : long wave generated by a timevarying break point, J. Geophys. Res., Vol.87, No.C1, pp.492-498, 1982.

4) Foda, M. A. and C. C. Mei : Nonlinear excitation of longtrapped waves by a group of short swells, J. Fluid Mech.,,Vol.111, pp.319-345,1981.

5) 佐藤昭二 ·森平倫生 - 入江 功 - 谷本勝利 : 駿河湾海 岸踏査報告, 港湾技術研究所報告, 第 6 巻, 第 7 号, pp.1-70, 1967.

6) 仲座栄三・日野幹雄 : リーフ地形海岸におけるBore状 サーフビートによる災害の実態調査, 第35回海岸工学 講演会論文集，pp.202-206，1988.

7) 佐藤懭司 - 小杉俊夫 · 加藤憲一 - 口石孝幸 : 西泪海岸 に扔ける台風 9720 号による海岸災害とその原因，海岸 工学論文集, 第45巻, pp.326-330, 1998.

8) 佐藤㥀司 - 河野龍男 - 諸田 勇 · 桜庭雅明 - 加藤俊 夫：駿河海岸に扔ける台風来襲時の波浪特性と越波実 態, 海岸工学論文集, 第46巻, pp.766-770,1999.

9) 平石哲也 - 末松忠敬 - 楠瀬洋 - 島元民男 - 鈴木善光 · 棉原弘・殿最浩司：緩傾斜護岸の波の打ち上げ高㧍よ び越波に及ぼす長周期波の影響に関する現地調查, 海 岸工学論文集, 第45巻, pp.671-675, 1998

10) 田中征夫 · 溝辺 哲 - 岡部光成 : 苓北地点9119号台風 災害の原因究明と復旧対策, 電力土木, No.242, pp.81$89,1992$.

11) 清水环三 ·金山 進 - 服部 武 - 武藤亮介 - 高木伸 雄 -二見耕左 : 漁港内の長周期波に関する現地観測, 海岸工学論文集, 第41巻, pp.61-65,1994.

12) 平石哲也・田所篤博・藤媄秀可：港湾で観測された長 周期波の特性，港湾技術研究所報告，第36巻，第3号， pp.3-36,1996.

13) 平石哲也 - 白石 悟 - 永井紀彦 - 横田 弘 - 松㴊 知・藤咲秀可 · 清水勝義：長周期波による港湾施設の 被害特性とその対策工法に関する調査，港湾技研資料， No.873,39p,1997.

14) 仲座栄三 - 津嘉山正光 - 日野幹雄 - 大城 勉 : 波群津 波の津波波力に関する研究，第35回海岸工学講演会論 文集, pp.597-601, 1988.

15) 合田良実：浅海域に扔ける波浪の砕波変形，港湾技術 研究所報告, 第14巻，第3号，pp.59-106,1975.

16) 山口正隆 - 畑田佳男: 波浪に伴う長周期波の統計的特 性について, 第30回海岸工学講演会論文集, pp.148$152,1983$.

17) Katoh, K. : Multiple longshore bars formed by long period standing waves, Rept. Port and Harbour Res. Inst., Vol.23. No.3, pp.3-46,1984.

18) Bowers,E.C. : Low frequency waves in intermediate water depths, Proc. $23^{\text {rd }}$ ICCE, pp.832-845,1992.

19) 渥美洋一 · 若山義樹·國田淳 ·関口信一郎 - 川口 勉・平石哲也・青木伸一・上田 茂：長周期波の港内 侵入過程の現地観測と長周期波高予測式の検討，海岸 工学論文集, 第44巻, pp.221-225,1997.

20）山村易見·青木伸一：外洋に面した小規模港湾内外に 㧍ける長周期波の挙動, 海岸工学論文集, 第 45 巻, pp.311-315,1998.

21）堀沢真人·佐藤典之.大中 晋·青野利夫 · Cruz., C. Eric · 早川淳：港内外長周期波の現地観測とその予測手法, 海岸工学論文集, 第45巻, pp.301-305,1998.

22) 平石哲也・河野信二・玉城重則・長谷川準三：港湾構 造物の設計に用いる長周期波の標準スペクトルについ て, 海岸工学論文集, 第44巻, pp.246-250,1997.

23) 関本恒浩 - 清水环三・窪 泰浩 - 今井澄雄 - 島津昌 央：港湾内外のサーフビートの発生伝播に関する現地 調査, 海岸工学論文集, 第37巻, pp.86-90,1990.

24) 佐藤懭司：浅海域における長周期流速変動の発達特性, 海岸工学論文集, 第44巻, pp.256-260,1997.

25) 中畑禎 - 落合敏浩 - 柏原裕彦 - 花山格章 - 森屋陽一 関本恒浩：冬期日本海の現地観測に基づく浅海域への 入射長周期波の評価, 海岸工学論文集, 第 48 巻, pp.256-260, 2001. 
26) 中畑禎 - 落合敏浩 - 柏原裕彦 - 花山格章 - 関本恒浩： 現地観測に基づく長周期波の沿岸方向特性, 海岸工学 論文集, 第48巻, pp.261-265, 2001 .

27)（財）沿岸開発技術研究センター：CADMAS-SURF数 值波動水路の研究・開発, pp.214-223,2001.

28) 喜岡 渉 - 飯田耕三·石田昭：非線形長周期波の 湾水振動, 第 35 回海岸工学講演会論文集, pp.242-246,1998.

29) 喜岡 渉 - 川合正恭 - 田村真一：非線形変調波 に伴う長周期水位変動について, 海岸工学論文 集，第37巻, pp.91-95,1990.

30) 仲座栄三.日野幹雄 - 津嘉山正光 - 大城 勉 : リーフ地形海岸に抢ける防波堤に作用する波力 に関する研究, 海岸工学論文集, 第 36 巻, PP.589-593,1989.

31) 関本恒浩·近藤浩右 · 藤谷昌弘 - 今井澄雄 · 黒 田輝夫：波群特性とサーフビートを考慮した防 波堤堤頭部の設計波力について, 海岸工学論文 集，第37巻，pp.626-630,1990.

32) 清水环三・鵜飼亮行 · 片山裕之 · 金山 進 - 川 俣 奨・近藤浩右：島提の滑動安定性に及ぼす 長周期波の影響について，海岸工学論文集，第 42巻, pp.856-860,1995.

33) 清水环三・鵜飼亮行 - 金山 進 · 川俣 奨 - 片 山裕之：混成堤マウンド近傍流速に及ぼす長周 期波の影響，海岸工学論文集，第43巻，pp.881$885,1996$.

34) Bowers,E.C. : Harbour resonance due to set-down beneath wave groups, J.F.M., Vol. 79, Part 1, pp.7192,1977 .

35) 喜岡 渉 - 飯田耕三·石田昭 : 非線形長周期波の 湾水振動, 第 35 回海岸工学講演会論文集, pp.242-246,1988.

36) Mei, C. C. And Y. Agnon : Long-period oscillations in a harbour induced by incident short waves, J. Fluid Mech., Vol.209, pp.595-608,1989.

37) Wu, J.-K. And P. L.-F. Liu : Harbour excitations by incident wave groups, J. Fluid Mech., Vol.217, pp.595-613,1990.

38) 関本恒浩・森屋陽一・水口優：自由長周期波の発生と その定量的評価に関する理論的考察，海岸工学論文集, 第47巻, pp.236-240,2000.

39) 喜岡 渉 - 柏原謙爾 - M., Dibajinia - 平石哲也：ラ ディエーションストレスによる港内長周期波の計算モ デル，海岸工学論文集，第46巻，pp.296-300,1999.

40) 金山 進 ·田口 智 - 清水环三 · 長舩 徹 - 植 木一浩・中原和彦：ブシネスク方程式による港 内長周期水位変動の数値計算, 海岸工学論文集, 第42巻, pp.291-295,1995.

41) 喜岡 渉 ·柏原謙爾：2次長周期波の湾水振動に 及ぼす来襲波の多方向性の影響，海岸工学論文 集，第42巻，pp.296-300,1995.

42) 藤畑定生 · 秦 禎勝 - 森屋陽一 - 中山晋一 · 関本恒 浩：現地観測による港内長周期波浪流速特性とその予 測方法に関する検討, 海岸工学論文集, 第 45 巻, pp.306-310,1998.

43) 永井紀彦・橋本典明 - 浅井 正 · 戸引 勲 - 伊藤一 教・東江隆夫・小林昭男・柴田孝雄 : 現地デー夕に基 づく港内係留船舶の動摇に及ぼす港外長周期波，海岸 工学論文集, 第41巻, pp.931-935,1994.

44) 松良精三・渥美洋一・菅沼史典・宮本義憲：波群に拘 束された長周期波の港内における増幅特性と船体動摇 に関する現地観測, 海岸工学論文集, 第41巻, pp.7175,1994 .

45）菅沼史典・神谷昌文・渥美洋一・小泉信男：現地観測 による長周期波の発生頻度と船体動摇発生予測の検 討，海岸工学論文集，第42巻, pp.951-955,1995.

46) 神谷昌文・渥美洋一 - 國田 淳 - 関口信一郎 · 木村克 俊・平石哲也・白石 悟 ·上田 茂: 長周期波に刘与 る荷役稼働率の評価法とその改善策, 海岸工学論文集, 第43巻, pp.891-895,1996.

47) 田端竹千穂・田所篤博 - 平石哲也 -玉城重則：港湾に おける長周期波の増幅現象に関する現地観測，海岸 工学論文集，第42巻，pp.301-305,1995.

48) 朝崎勝之・松尾憲親 - 藤畑定生 - 鵜飼亮行 · 清水环 三：港内副振動に関する現地観測と長周期波を考慮し た荷役稼働率の評価, 海岸工学論文集, 第 43 巻, pp.886-890,1996.

49) 藤畑定生 - 秦 禎勝 - 中山晋一 - 森屋陽一 - 関本恒 浩・池野正明・笹 健児：船体動摇計算における港内 副振動の考慮方法と粘性減衰係数の評価, 海岸工学論 文集，第46巻，pp.856-860，1999.

50) 平石哲也 ·藤咲秀可 - 近藤充隆 - 佐藤恒夫 · 山口孝 市：鹿島港における長周期波の長期観測, 海洋開発論 文集，Vol.13，pp.141-146，1997.

51) 白石悟 - 久保雅義 - 榊原繁樹 - 笹健児 : 長周期船体動 摇の数值計算による再現性に関する研究, 海岸工学論 文集，第46巻, pp.861-865,1999.

52) Bowen, A. J. And D. L. Inman : Edge waves and crescentic bars, J. Geophys. Res., Vol.76, No.36, pp.8662-8671,1971.

53) Short, A. D. : Multiple offshore bars and standing waves, J.G.R.,Vol.80, No.27, pp.3838-3840,1975.

54) 松岡道男 - 木下勝尊 - 山本正昭 - 森口朗彦：長 周期水理特性を考慮した港内堆砂モデルの適用 性の検討, 海岸工学論文集, 第38巻, pp.416420,1991 .

55) 柴山知也 - 斉藤栄一 - 正田克己 - 奥野雅量 - 岡 安章夫：長周期波の局所漂砂量に及ぼす効果, 海岸工学論文集，第37巻, pp.279-283,1990.

56) 佐藤琂司・光信紀彦：不規則波による海浜断面 地形変化の数值計算, 海岸工学論文集, 第37巻, pp.309-313,1990.

57) 加藤一正 - 柳嶋慎一 - 栗山善昭 - 磯上知良：荒 天時のバーム地形の侵食, 一長周期波に着目し た現地観測—, 海岸工学論文集, 第 36 巻, pp.354-358,1989.

58) Mohammad, D. ·樋川直樹・渡辺 晃：長周期波を 含む非対称不規則波浪下でのシートフロー漂砂, 海岸工学論文集, 第45巻, pp.471-475,1998. 